\title{
XLVII. Experiments to ascertain whether there exists any affinity betwixt carbon and clay, lime and silex, separately or as compounds united with the oxide of iron forming iron ores and iron stones
}

\section{David Mushet Esq.}

To cite this article: David Mushet Esq. (1804) XLVII. Experiments to ascertain whether there exists any affinity betwixt carbon and clay, lime and silex, separately or as compounds united with the oxide of iron forming iron ores and iron stones, Philosophical Magazine Series 1, 19:75, 275-282, DOI: 10.1080/14786440408676564

To link to this article: http://dx.doi.org/10.1080/14786440408676564

$$
\text { Published online: } 18 \text { May } 2009 .
$$

Submit your article to this journal ए

$$
\text { Џll Article views: } 2
$$

Q View related articles $\sqsubset$ 
On the Affinities of different Earths for Carlion. 275

lent ether, may be collected in a very short time, The ether has a weak orange colour, with a very agreeable smell: it does not change blue vegetable colour to red; and exhibits in general all the phænomena of the best nitrous ether,

During the formation of the ether there is disengaged some nitrous gas, which may be known by a red vapour diffused throughout the apparatus. When this vapour appears, the receiver must be changed. The sugar which remains in the retort may be easily converted into oxalic acid by treating it with a fresh quantity of nitrous acid.

XIVII. Experiments to ascertain whether there exists any Affinity betwixt Carbon and Clay, Lime and Silex, separately or as Compounds united with the Oxide of Iron forming Iron Ores and Iron Stones. By DAvid Mushet, Esq, of the Calder Iron-Works.

[Continued from p. 14x.]

$\mathrm{H}$ AviNG thus ascertained certain peculiar affinities betwixt carbon and clay and silex, manifested by the disappearance of the former, when exposed to melting heats in contact with the latter, I now proceeded to investigate what effects would be produced in the revivification of iron from ores compounded with various proportions of mixture.

I combined malleable iron with oxygen, and thus formed a considerable portion of rich oxide. This was pounded, and afterwards mixed with various earths and proportions of carbon. Thus prepared, it was found to contain,

$$
\begin{array}{lccc}
\text { Iron } & - & - & 74 \\
\text { Oxygen } & - & - & 24 \\
\text { Moisture } & - & - & 2 \\
& &
\end{array}
$$

The following experiments were made with this oxide and carbon, to ascertain the proportions of carbon neces. sary to revive a given quantity of iron.

I. 200 grains of oxide were fused per se. A very dense glass of iron was obtained with a partially crystallized fracture. The surface contained some beautiful crystallizations of detached radii possessed of various shades of colour; but no appearance of revived iron.

I. 200 grains of oxide,

5 - of carbon, or 1-40th. 
The fusion of this mixture afforded glass of iron less perfect than the former. The fracture divided itself into two distinct beds. The under one was a smooth black shining glass : the upper possessed a similar fracture and appearance to what was obtained in No. I. This difference was evidently the result of the combination of the small portion of carbon : for in the smooth black glass a disposition of the metal to separate was manifested by the formation of a minute cell exactly in the centre of the glass. This cavity is uniformly.obtained in all experiments of this nature, and is sometimes found containing beautiful prismatic colours and possessed of an uncommon degree of lustre.

III. 200 grains of oxide, 8 of carbon, or 1-25th part.

The fusion of this mixture afforded a very reat spherule of metal, which was found to weigh 8 grains or 4 per cent., or 1 grain of metal for 1 grain of carbon. The glass was black and shining throughout, resembling very much the lustre and polish of a highly finished razor. The iron obtained was soft and ductile. It easily flattened without cracking when cold, and exposed a fine gray spotted shale.

JV. 200 grains of oxide,

$$
10 \frac{2}{2} \text { of carbon, or 1-20th. }
$$

The result of the fusion of this mixture was a minute though elegant spherule of iron, possessing some fine watery shades. It was found to weigh 10 grains, or equal to 5 per cent. This, as in No. III, is exactly 1 grain of iron for every grain of carbon added. The glass in this experiment was still more shining and perfect than in the former, and the quality of the iron was equally soft and malleable.

V. 200 grains of oxide, 20 - of carbon, or 1-10th.

An elegant ovular button of iron was obtained in this experiment; the surface was possessed of an uncommon lustre and polish, contrasted by a variety of shades. It weighed exactly 56 grains, or equal to 28 per cent. The quantity of iron revived is nearly $2 \frac{3}{2}$ grains for each grain of carbon in the mixture.

The glass was not perceptibly different from that of No. IV, The quality of the iron was malleable, though not so soft and ductile as in former experiments.

VI. 200 grains of oxide,

$$
30-\text { of carbon, nearly } 1-7 \text { th. }
$$

From the fusion of this mixture a very smooth beautiful metallic button was obtained, which was found to weigh 
94 grains, and equal to 47 per cent. The proportion of iron revived in this experiment exceeds 3 grains for each grain of carbon. The surface of the glass was striated, of a blueish white pearly colour. The fracture, however, resembled the glasses obtained in Expcriments III, IV, and V. A few faint impressions of crystallization were observable upon the under surface of the mietallic button. This always indicates a combination of carbon, and uniformly announces a change to the state of steel.

VII. 200 grains of oxide, 40 of carbon, or 1-5th.

This mixture was reduced in 15 minutes, and a perfect metallic button obtained, which weighed 123 grains, equal to $61 \frac{1}{2}$ per cent. The quantity of metal revived was nearly in the same proportion to charcoal as in the former experiments. The quantity of glass was now considerably diminished, and was not sufficient to cover the upper surface of the button. In point of colour and opacity, however, it was not materially different from Exp. V and VI. The quality of the revived iron was highly decarbonated, of a white crystalline fracture.

VIII. 200 grains of oxide, 50 - of carbon, or 1-4th.

From the fusion of this mixture there resulted a partially crystallized button of crude iron which weighed 140 grains, or equal to 70 per cent. The glass had entirely disappeared, excepting a thin crust of a blackish green colour, attached to the edges of the button. The proportion of iron revived to carbon in this experiment is as $2 \frac{3}{4}$ to 1 .

IX. 200 grains of oxide,

60 - of carbon.

The fusion of this mixture yielded a very perfect metallic button which wcighed - $\quad$ - $140 \mathrm{grs}$.

Globules of a silvery colour thrown against the

sides of the crucible

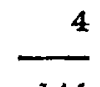

144

Equal to 72 per cent.

In this experiment only a very thin film of glass was found of a light lead blue colour; and, as there remained untaken up 4 grains of the charcoal, it is presumable that the whole contents in iron contained in the oxide, making allowance for unavoidable loss, was now revived and collected together. As the quality of the metal now obtained was still highly deficient in carbon, it appeared probable Vol. 19. No. 75. August 1804. that 
that by carbonating the product a larger quantity by weight would be obtained.

$\mathrm{X} .200$ grains of oxide, 100 - of earbon.

This proportion of mixture was found but partially fusible. A considerable portion of iron was revived in large and small globules beautifully carburated. Part of the moleculæ of the oxide had lost its oxygen, and was either resolved into an imperfect carburet with the charcoal, or into minute malleable grains of iron.

XI. 400 grains of oxide, 200 - of charcoal.

Although the proportions in this experiment were the same as in the former, yet a perfect reduction was effected, and a fine button of carbonated metal abtained which weighed - - - - - 280 ges.

Globules thrown up in the ebullition of the metal - $\quad$ - $\quad-\quad 12$

Equal to 73 per cent. $\quad-\frac{19}{292}$

The under surface of the product now obtained was richly carburated, the top plain and smooth. The fracture open and gray, resembling No. I, (or smooth-faced) pig iron.

The different results of these two last experiments are one of the many instances which occur in this department of metallurgy, where the perfection of the operation depends more upon the quantity of matter used than the direct proportions of the mixture.

The deductions which are liable to be made, arising from this source of error, are sometimes most erroneous, and frequently beyond belief. For example:

XII. 1750 grains of exide, $87 \frac{1}{2}-$ of charcoal, or 1-20th.

This mixture was fased into a dead ponderous glass of iron wherein no trace of revived metal could be found : now in Experiment IV, the same proportion of mixture yielded 5 per cent. of iron. Again,

XIII. 1750 grains of oxide,

175 - of charcoal, or $1-10$ th.

The fusion of this, mixture afforded a black, shining, heavy glass, without the most minute particle of revived metal. In Experiment $V$, with the same proportions of oxide and earbon, 28 per cent. of iron was revived.

XIV. 1750 grains of oxide, 250 of charcoal, or $1-7$ th. 
This mixture was perfectly fused, and equally destitute of revived iron as the former. In Experiment $\mathrm{VI}$, the same proportion of mixture yielded 47 per cent. of iron. I afterwards found that, when this quantity of oxide was used; the first symptoms of separation took place with 1-5th its weight of charcoal.

I know of no satisfactory reason which can be given to solve the material difference of the results in these experiments, simply arising from quantity, unless the additional exposure requisite to reduce the large quantity destroys a greater portion of the charcoal uselessly than when the small portion of matter is operated upon. The process of separation divides itself into branches. The first consists in the action of a well known affinity,-the combination of the carbon with the oxygen of the oxide, which leaves the particles of metal highily disposed to become the subject of the second affinity, viz. the combination of the carbonaceous matter with the iron. Now, if we suppose that in both series of experiments there existed in each mixture a particle of carbon for every particle of metal, and one for every particle of oxygen (if I am allowed the expression), then we cannot see that in either operation a difference of result should take place, provided the experiments are alike accurately performed, and the time of exposure similar. The fact, however, turns out very differently, and, I make no doubt, is guided by some regular and well established cause. May not the last portions of oxygen be more difficult to remove from the large than from the small quantity? or, in other words, May they not require a greater dose of carbon to saturate them under the double circumstance of increased quantity and approximation to fusion?

Although I could not reduce the mixture operated upon in Exp. $X$, I found this easily effected by the addition of chalk.

XV. Oxide of iron - $\quad 200 \mathrm{grs}$.

$$
\begin{aligned}
& \text { Charcoal - - - } 100 \\
& \text { Chalk - - - } 100
\end{aligned}
$$

But in place of finding the revived iron carburated as in that experiment, I found it quite the reverse.

A review of these experiments performed with pure iron, oxygen, and carbon, will convey a pretty accurate idea of the real quantity of the latter necessary to revive certain portions of iron. It is however most difficult to decide what portion of the carbon unites to the oxygen of the oxide, and what to the metallic part. I have uniformly found that all iron ores and oxides take up a portion of carbon before any of the metal is separated. This combination $\mathrm{U}_{2}$ brings 
brings the glass of iron more and more to the metallic. state, undoubtedly by removing a portion of the oxygen, This appears most evident from Experiments III and IV, where only one grain of metal was revived by each grain of charcoal in the mixture. As the quantity of oxygen by this means became reduced, we find that the quantity of iron revived increased in a greater ratio, and at some times exceeded 3 to 1 of the charcoal. (See Experiments VI and VII.)

Recapitulation of these Experiments, and the Rate of Charcoal at which the metallic Particles become revived.

Exp. I. Fusion per se, afforded no metal.

II. Oxide, and 1-40th of charcoal; no metal.

III. ditto $-1-25$ th of ditto; 4 per cent. of iron revived

IV. ditto - I-2oth of ditto, 5 per cent.

V. ditto - 1-10th of ditto, 29

VI. ditto $-1-9$ th of ditto, 47

VII. ditto $-1-5$ th of ditto, $61 \frac{1}{2}$

VIII. ditto - J-4th of ditto, 70

In these eight experiments tise charcoal had totally disappeared.

IX. ditto and 1-3d of ditto, 72

Along with which was found a residuum of 4 grains of carbon.

It is also worthy of remark, that in the early proportions of charcoal, when one-half of the metallic contents only are revived, the metal is then discharged from the oxide in a state of complete malleability, though highly red-short. This takes place in all experiments of this nature with a sufficient dose of carbon; and I have frequently taken advantage of this circumstance to form an opinion of the properties and strength of the malleable iron which any giren ore was likely to afford from the manufacture of the pig.

Part of the metallic contents of any ore or oxide being thus precipitated by means of charcoal in a state of uncommon softress and ductility, we are led to infer that any additional portion of carbon would only increase the quantity of malleable iron, and ultimately produce the whole contents of the ore in a state of malleability. This, however, is by no means the çase; for as soon as nearly one-half the metal is revived, a more powerful affinity is establisbed betwixt it and the additional carbon. Steel or crude iron is formed through the whole mass by this extra combination, and every appearance of softness and malleability vanishes. This takes 
place when nearly 3-4ths of the whole metal is revived, and decidedly proves a reverse of affinity to what at first existed.

At the beginning of the experiment we find that the charcoal prefers uniting with the general body of oxygen, rather than clearing a minute portion and reviving its appropriate metal. This takes place till a considerable part of the oxygen is dissipated. In the progress of this, the affinity betwixt the carbon and iron is gradually developed; and before it is fully established a portion of the iron is precipitated in a malleable state, not as a direct consequence of the union of the carbon with it, but in consequence of the oxygen of the oxide being removed, and the particles left in a metallic state. So long as this takes place, I look upon the affinities of carbon for the remaining oxygen of the ore, and for its metallic contents; as nearly balanced; and this will always have a direct reference to the proportion of each. When this equilibrium is destroyed by the addition of certain extra portions of carbon, a paramount affinity is immediately established betwixt these and the iron which had before been separated in the malleable state, and steel or crude iron of various degrees of saturation proportioned to the carbon is the result.

From another mode of operation it is pretty evident that this reverse of affinity is occasioned in a great measure by the temperature, particularly as in the above case, where it uniformly is productive of fusion. If the same oxide here operated upon, or indeed any ore, is exposed to a temperature in contact with charcoal considerably short of fusion, a deoxidation nearly complete will take place, provided the experiment as to proportion of mixture and time has becn properly conducted. The matter thus exposed will be found to have lost considerably in weight by the loss of oxygen. If it is carefully freed from the surrounding charcoal, washed, and immediately dried and introduced into a clay crucible and exposed to a very high heat, a button of metal will be found, amounting to 8-10ths or 9-10ths, the whole produce in iron which the ore contained. This iron will be in the state of malleability nearly as soft as copper when cold, but uncominonly red-short when heated beyond a bright red, The deficient iron, amounting to 1 or $2-10$ ths, will be frund in a small portion of glass of iron attached to the edges of the button, and which may be easily called to existence by the addition of a few grains of carbon.

This still proves that the temperature employed in cementation, though adequate to remove the greatest part of the oxygren, yet is insufficient to dissipate its last remains. 
To effect this, a higher temperature and a more powerful affinity must be exerted. That this effect is complete we have no proof, but that a larger portion of metal is called into existence. If the affinity continues to increase in the ratio of the diminution of the quantity, then a much higher temperature and a more powerful affinity may be requisite to remove from iron the last portions of oxygen than any with which we are acquainted.

The external characters assumed by iron separated in this simple mode of assaying, are of much importance in understanding thoroughly the process. As long as malleable iron continues to be precipitated, the metal, if covered with glass, possesses a surface of the highest polish. The colours are frequently various, chiefly shades of blue and azure, sometimes black-watery inclining to rich deep brown. The union of carbon, even in small quantities, under the same r.ressure of glass, is immediately known by the fine crystalline form which begins to spread over the surface: sometimes the entire surface is thus elegantly marked. As the quantity of carbon increases to form steel, the crystallization assumes a radiated structure, convex upon the upper surface and concave below. This form continues through all the states of steel, but in approaching to crude iron the under surface loses the concave and crystallization, and assumes a smooth skin, sometimes marked with hollows equally smooth. When the combination of carbon is sufficient to change the fracture of the metal from white to mottled or gray, evcry trace of crystallization then vanishes, and a surface comparatively rough, but highly convex on all sides, succecds.

\section{Notices respecting New Books.}

Mr. Parkinson, of Hoxton, to whom chemists are indebted for a very useful publication, the Chemical Pocket $B o o k$, of which we have more than once had occasion to speak, has just published the first volume of a new work, which will be found extremely interesting and useful to gcologists and mineralogists. It is entitled, An Examination of the mineralized Remains of the Vegetables and Animals of the Antediluvian World, generally termed extraneous Fossils, 4to, 471 pages and an index.

This volume, which contains the vegetable kingdom, is embellished and illustrated with a frontispiece and nine 